\title{
Reduction of carbonyl compounds via hydrosilylation catalyzed by well-defined PNP-Mn(I) hydride complexes
}

\author{
Stefan Weber ${ }^{1} \cdot$ Dina lebed $^{1} \cdot$ Mathias Glatz $^{1} \cdot$ Karl Kirchner $^{1}$ (D)
}

Received: 15 March 2021 / Accepted: 20 April 2021 / Published online: 14 June 2021

(c) The Author(s) 2021

\begin{abstract}
Reduction reactions of unsaturated compounds are fundamental transformations in synthetic chemistry. In this context, the reduction of polarized double bonds such as carbonyl or $\mathrm{C}=\mathrm{C}$ motifs can be achieved by hydrogenation reactions. We describe here a highly chemoselective Mn(I)-based PNP pincer catalyst for the hydrosilylation of aldehydes and ketones employing polymethylhydrosiloxane (PMHS) as inexpensive hydrogen donor.
\end{abstract}

Graphic abstract

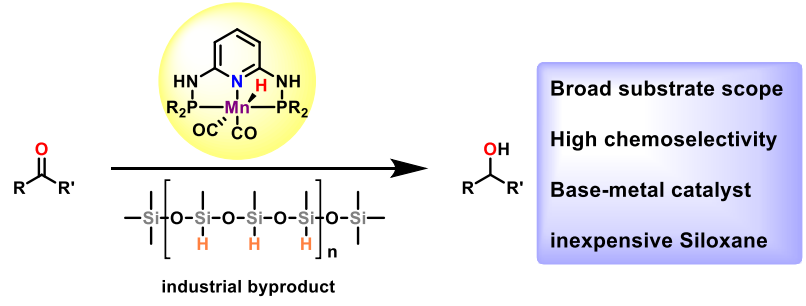

Keyword Manganese $\cdot$ Pincer complexes $\cdot$ Reduction $\cdot$ Silanes $\cdot$ Ketones

\section{Introduction}

The reduction of polarized double bonds such as carbonyl motifs is among the most important transformations in organic synthesis. To increase atom efficiency and avoid massive production of waste, catalytic reactions should be employed. Within this context, precious metals are frequently used. However, their production shows high environmental impact and their amount is limited. The usage of earth abundant metals would decrease the environmental impact and could be an interesting alternative to noble metals [1].

Within this context, manganese is an interesting candidate for investigations due to its low toxicity and high

Karl Kirchner

karl.kirchner@tuwien.ac.at

1 Institute of Applied Synthetic Chemistry, Vienna University of Technology, Getreidemarkt 9/163-AC, 1060 Vienna, Austria abundance [2]. Manganese-based complexes play a major role in sustainable oxidation [3-10] and hydrogenation [11-18] reactions by now. Although, the use of dihydrogen displays advantages such as low costs and easy removal from the reaction mixture, several drawbacks should be taken in account. Dihydrogen is explosive and expensive reactors have to be used. An attractive alternative to that is the use of hydrogen donors such as silanes [19, 20]. Since the first report on manganese-catalyzed hydrosilylation reactions by Yates and coworkers in 1982 [21], several protocols for the hydrosilylation of polarized double bonds such as ketones [22-27], esters [28, 29], amides [30-32] and acids [33] as well as alkenes [34-36] and alkynes [37] were developed.

Our group recently reported on the chemoselective hydrogenation of aldehydes, catalyzed by a well-defined PNP$\mathrm{Mn}(\mathrm{I})$ complex [15]. We wondered if the same complex is also capable of undergoing hydrosilylation reactions of carbonyl compounds and whether the substrate scope could be extended to ketones (Scheme 1). Here, we describe the chemoselective hydrosilylation of aldehydes and ketones 


\section{Scheme 1}

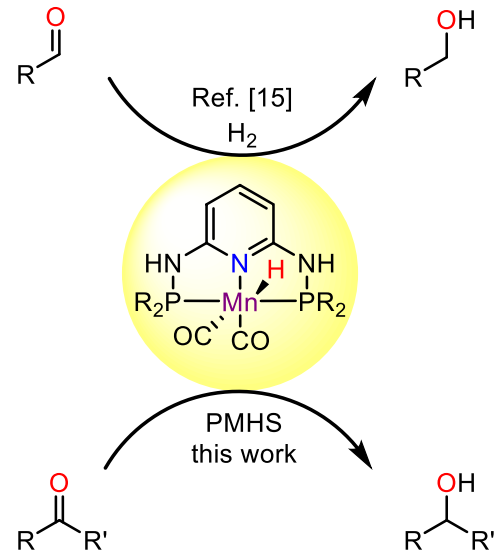

catalyzed by well-defined PNP-Mn(I) complexes based upon the 2,6-diaminopyridine scaffold (Scheme 2). As inexpensive silane source polymethylhydrosiloxane (PMHS) is utilized.

\section{Results and discussion}

To evaluate the potential use of PNP-based Mn(I) complexes, the hydrosilylation of 4-fluoroacetophenone with phenylsilane was chosen as model reaction utilizing complexes 1-4 as pre-catalysts. Conversions and yields were determined by ${ }^{19} \mathrm{~F}\left\{{ }^{1} \mathrm{H}\right\}$ NMR-spectroscopy $[13,18]$. While complexes $\mathbf{1}, \mathbf{3}$, and $\mathbf{4}$ are capable of metal-ligand bifunctionality, metal-ligand cooperation is blocked in the case of complex 2 due to methylation of the $N$-linker. As shown in Table 1, complexes $\mathbf{1}$ and $\mathbf{2}$ gave moderate to good conversion whereas compounds $\mathbf{3}$ and $\mathbf{4}$ did not show any reactivity for the hydrosilylation of 4-fluoroacetophenone. The hydride ligand seems to be vital for the activity of the system. Interestingly, complex $\mathbf{1}$ and $\mathbf{2}$ gave similar conversions indicating that metal-ligand cooperativity is not crucial for the hydrosilylation of ketones.

According to the results represented in Table 1, catalyst 1 was chosen for further investigations and optimization of

\begin{tabular}{llll}
$\begin{array}{l}\text { Table } 1 \\
\text { Cylation }\end{array}$ & $\begin{array}{c}\text { screening } \\
\text { of }\end{array}$ & $\begin{array}{c}\text { for } \\
\text { 4-fluoroacetophenone }\end{array}$ \\
\hline Entry & Catalyst & Conversion $/ \%$ & Yield $/ \%$ \\
\hline 1 & $\mathbf{A C N}, 80{ }^{\mathrm{a}} \mathrm{C}, 18 \mathrm{~h}$ & 65 \\
2 & $\mathbf{2}$ & 78 & 63 \\
3 & $\mathbf{3}$ & 70 & - \\
4 & $\mathbf{4}$ & - & -
\end{tabular}

Reaction conditions: $0.35 \mathrm{mmol}$ ketone, $2 \mathrm{~mol} \%$ catalyst, $0.1 \mathrm{mmol}$ $\mathrm{PhSiH}_{3}, 2 \mathrm{~cm}^{3} \mathrm{ACN}, 18 \mathrm{~h}, 80^{\circ} \mathrm{C}$

${ }^{\text {a }}$ Conversion determined via ${ }^{19} \mathrm{~F}\left\{{ }^{1} \mathrm{H}\right\}$ NMR-spectroscopy

${ }^{\text {b }}$ Yield determined via ${ }^{19} \mathrm{~F}\left\{{ }^{1} \mathrm{H}\right\}$ NMR-spectroscopy and fluorobenzene as standard

the reaction parameters. Since the use of phenylsilane as hydrogen-source is connected to high costs, we wondered if substitution by the inexpensive siloxane polymethylhydrosiloxane (PMHS) is possible. PMHS is a byproduct in industrial siloxane product and, therefore, displays an interesting candidate as hydrogen-source in hydrosilylation reactions [38]. To our delight, the substitution of phenylsilane with PMHS even increased the conversion to $92 \%$ (Table 2, entry 1). Increasing the reaction temperature to $110^{\circ} \mathrm{C}$ led to full conversion of substrate at only $1 \mathrm{~mol} \%$ catalyst (Table 2 , entry 4). However, the difference between determined conversion and yield was attributed to formation of a hemiacetal as side product.

Therefore, a screening of solvents was done to circumvent the formation of undesired byproduct. Toluene and THF gave low conversion, but no formation of hemiacetal could be detected. Employing isopropanol as solvent led only to traces of product formation. 1,2-Dimethoxyethane (DME) revealed to be the best solvent for this transformation, giving a clean reaction. To achieve good conversions, the catalyst loading was reinvestigated, whereas $2.5 \mathrm{~mol} \%$ gave the best results (Table 2, entry 10).

Scheme 2

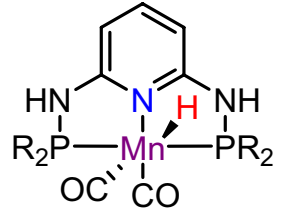

1

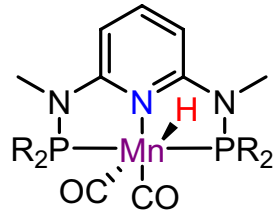

2

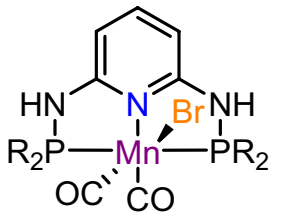

3

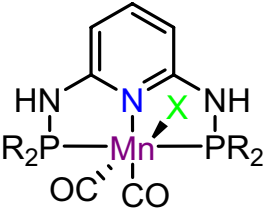

$\mathrm{X}=\mathrm{OCOH}$

$\mathrm{R}=i \operatorname{Pr}$ 


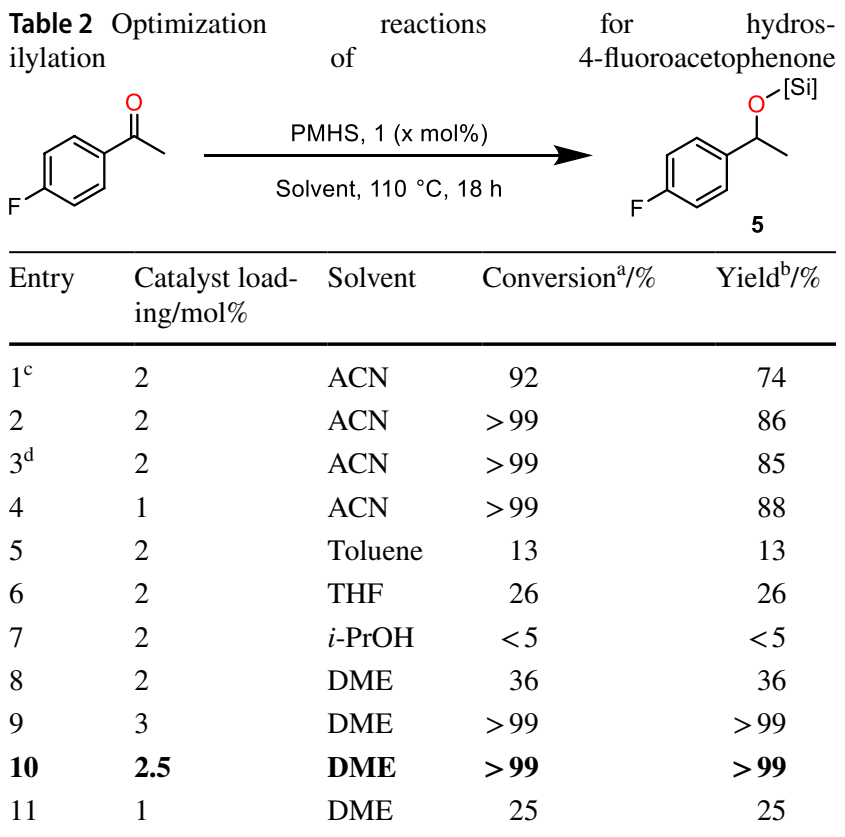

Reaction conditions: $0.35 \mathrm{mmol}$ ketone, $2.5 \mathrm{~mol} \% \mathrm{1}, 0.1 \mathrm{mmol}$ $\mathrm{PhSiH}_{3}$ or $0.035 \mathrm{mmol}$ PMHS (average MW $1850 \mathrm{~g} / \mathrm{mol}$ ), $2 \mathrm{~cm}^{3}$ solvent, $18 \mathrm{~h}, 110^{\circ} \mathrm{C}$

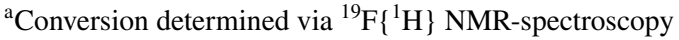

${ }^{b}$ Yield determined via ${ }^{19} \mathrm{~F}\left\{{ }^{1} \mathrm{H}\right\}$ NMR-spectroscopy and fluorobenzene as internal standard

${ }^{\mathrm{c}} 80^{\circ} \mathrm{C}$

${ }^{\mathrm{d}} 0.05$ equiv. PMHS

Having established the optimized reaction conditions, the scope and limitation was investigated and a broad variety of different (hetero)aromatic substrates was examined. The introduced procedure tolerated halides (7) as well as coordinating groups such as amine (10), ether (9), and nitrile (11) functionalities. It should be noted, that high chemoselectivity towards the reduction of the keto-group in the presence of a nitrile moiety could be detected, whereas the nitrile functionality stays unaltered. Lower conversion could be achieved in the presence of a nitro-group $(\mathbf{8})$. Sterically more demanding ketones (14 and 15) gave excellent yields. Furane (18)- and pyridine (17)-based systems gave good yields. Lower reactivity could be observed in case of aliphatic systems (19 and 20). However, no reduction of the conjugated $\mathrm{C}-\mathrm{C}$ double bond could be detected in case of $\mathbf{2 0}$.

The substrate scope was further extended to aldehydes. The challenging substrate salicylaldehyde (21) gave excellent yield. Due to the high chemoselectivity of catalyst $\mathbf{1}$, a variety of challenging aldehydes containing $\mathrm{C}-\mathrm{C}$ double bonds was investigated. Cinnamon aldehyde (22) as well as 1-methyl-1-butene-carbaldehyde (25) gave good to excellent conversion, without any reduction of the conjugated $\mathrm{C}-\mathrm{C}$ double bond. Finally, aldehydes, which are important compounds in fragrance industry were investigated. Excellent yields could be detected in case of helional (24), citronellal (26), and citral (27) as substrates. Unfortunately, only low conversion could be detected in case of dartanal (29) (Table 3).

\section{Conclusion}

In sum, we have described an efficient manganese-catalyzed hydrosilylation of aldehydes and ketones with the inexpensive siloxane PMHS, which is a byproduct in industry. High chemoselectivity for the reduction of carbonyl groups in the presence of (conjugated) $\mathrm{C}-\mathrm{C}$ double bonds or other reducible groups such as nitro or nitrile functionalities could be reported. The scope of the introduced protocol covered a broad variety of aromatic ketones. In the case of aldehydes, challenging substrates featuring (conjugated) $\mathrm{C}-\mathrm{C}$ double bonds were chosen which are important in the fragrance industry.

\section{Experimental}

All manipulations were performed under an inert atmosphere of argon using Schlenk techniques or in an MBraun inert-gas glovebox. The solvents were purified according to standard procedures [39]. The deuterated solvents were purchased from Aldrich and dried over $4 \AA$ molecular sieves. Complexes $\left[\mathrm{Mn}(\mathrm{PNP}-i \mathrm{Pr})(\mathrm{CO})_{2} \mathrm{H}\right](\mathbf{1})$, $\left[\mathrm{Mn}\left(\mathrm{PNP}^{\mathrm{Me}}-i \mathrm{Pr}\right)(\mathrm{CO}){ }_{2} \mathrm{H}\right](\mathbf{2}),\left[\mathrm{Mn}(\mathrm{PNP}-i \mathrm{Pr})(\mathrm{CO})_{2} \mathrm{Br}\right]$ (3), and $\left[\mathrm{Mn}(\mathrm{PNP}-i \mathrm{Pr})(\mathrm{CO})_{2}\left(\kappa^{1}-\mathrm{O}-\mathrm{OCHO}\right)\right](4)$ were prepared according to the literature $[15,40,41] .{ }^{1} \mathrm{H}$ NMR spectra were recorded on Bruker AVANCE-250 and 400. ${ }^{1} \mathrm{H}$ NMR spectra were referenced internally to residual protio-solvent, and solvent resonances, respectively, and are reported relative to tetramethylsilane $(\delta=0 \mathrm{ppm})$. ${ }^{19} \mathrm{~F}\left\{{ }^{1} \mathrm{H}\right\}$ NMR spectra are reported relative to trichlorofluoromethane $\left(\mathrm{CFCl}_{3}\right)(\delta=0 \mathrm{ppm})$. GC-MS analysis was conducted on an ISQ LT Single quadrupole MS (Thermo Fisher) directly interfaced to a TRACE 1300 Gas Chromatographic systems (Thermo Fisher), using a Rxi-5Sil MS (30 m, $0.25 \mathrm{~mm}$ ID) cross-bonded dimethyl polysiloxane capillary column.

\section{General procedure for hydrosilylation reactions}

Inside an Ar-flushed glovebox, an $8 \mathrm{~cm}^{3}$ microwave vial was charged with complex (0.01-0.03 mol\%), carbonyl substrate $(0.35 \mathrm{mmol}), 2 \mathrm{~cm}^{3}$ solvent, and silane $(0.035-0.1 \mathrm{mmol})$ in this order. A stirring bar was added, and the vial was sealed. The closed vial was removed from the glovebox and stirred for $18 \mathrm{~h}$ at the indicated temperature in a heated aluminum block. The vial was allowed to reach room temperature and 
Table 3 Scope and limitation of the hydrosilylation of carbonyls catalyzed by $\mathbf{1}$

$$
{\stackrel{\mathrm{R}}{\mathrm{R}^{\prime}}}_{2.20 \% \mathrm{NaOH}, 25^{\circ} \mathrm{C}, 18 \mathrm{~h}}^{\text {1. } 0.1 \text { eq. PMHS, } 1(2.5 \mathrm{~mol} \%), \mathrm{DME}, 110^{\circ} \mathrm{C}, 18 \mathrm{~h}}
$$<smiles>CC(O)c1ccccc1</smiles>

\section{6}

$93 \%$<smiles>CC(O)c1cccc(N)c1</smiles>

10

$>98 \%$<smiles>CCC(O)c1ccccc1</smiles>

14

$96 \%$

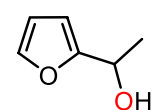

18

$91 \%$<smiles>OC/C=C/c1ccccc1</smiles>

22

$89 \%$<smiles>CC(O)c1ccc(Br)cc1</smiles>

$>98 \%$<smiles>CC(O)c1ccc(C#N)cc1</smiles>

11

$>98 \%$<smiles>CC(C)C(O)c1ccccc1</smiles>

15

$93 \%$<smiles>CC(O)Cc1ccccc1</smiles>

19

$87 \%^{a}$<smiles>OCC(c1ccccc1)c1ccccc1</smiles>

23<smiles>CC(O)c1ccc([N+](=O)[O-])cc1</smiles>

$65 \%^{a}$<smiles>COc1ccc(C(C)O)cc1</smiles>

$>98 \%$<smiles>OC(c1ccccc1)c1ccccc1</smiles>

12

$97 \%$<smiles>OC1CCc2ccccc21</smiles>

16

$82 \%$<smiles>CC(O)C=Cc1ccccc1</smiles>

20

$23 \%^{a}$<smiles>CC(CO)Cc1ccc2c(c1)OCO2</smiles>

24<smiles>CC(O)c1ccc2ccccc2c1</smiles>

13

$96 \%$<smiles>CC(O)c1ccncc1</smiles>

$85 \%$<smiles>OCc1ccccc1O</smiles>

21

$92 \%$<smiles>CC(C)=CCC[C@H](C)CCO</smiles>

26
$>98 \%$<smiles>CC/C=C(\C)CO</smiles>

25<smiles>CC(C)=CCC/C(C)=C/CO</smiles>

27

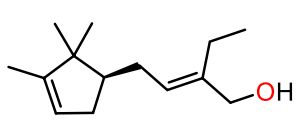

28

$95 \%$

Reaction conditions: $0.35 \mathrm{mmol}$ substrate, $2.5 \mathrm{~mol} \%$ 1, $0.035 \mathrm{mmol}$ PMHS (average MW $1850 \mathrm{~g} /$ $\mathrm{mol}), 2 \mathrm{~cm}^{3} \mathrm{DME}, 18 \mathrm{~h}, 110{ }^{\circ} \mathrm{C}$ in closed microwave vial; isolated yields

${ }^{\mathrm{a}}$ Conversion determined via GC-MS

the reaction was quenched by exposure to air. In case of screening reactions, fluorobenzene $(0.35 \mathrm{mmol})$ was added and the reaction mixture was analyzed by ${ }^{19} \mathrm{~F}\left\{{ }^{1} \mathrm{H}\right\} \mathrm{NMR}$.

\section{Isolation of the product}

To the reaction mixture $2 \mathrm{~cm}^{3}$ of a $20 \mathrm{wt} \% \mathrm{NaOH}$-solution were added and the solution was stirred for $18 \mathrm{~h}$ at room 
temperature. The phases were separated, and the aqueous phase was three times extracted with $2 \mathrm{~cm}^{3}$ diethyl ether. The combined organic phases were filtrated over a pad of silica, dried over $\mathrm{Na}_{2} \mathrm{SO}_{4}$ and the solvent was removed. Spectroscopic data of all isolated products are in line with the literature [11, 42-49].

Supplementary Information The online version contains supplementary material available at https://doi.org/10.1007/s00706-021-02774-y.

Acknowledgements Financial support by the Austrian Science Fund (FWF) is gratefully acknowledged (Project No. P 33016-N).

Funding Open access funding provided by Austrian Science Fund (FWF).

Open Access This article is licensed under a Creative Commons Attribution 4.0 International License, which permits use, sharing, adaptation, distribution and reproduction in any medium or format, as long as you give appropriate credit to the original author(s) and the source, provide a link to the Creative Commons licence, and indicate if changes were made. The images or other third party material in this article are included in the article's Creative Commons licence, unless indicated otherwise in a credit line to the material. If material is not included in the article's Creative Commons licence and your intended use is not permitted by statutory regulation or exceeds the permitted use, you will need to obtain permission directly from the copyright holder. To view a copy of this licence, visit http://creativecommons.org/licenses/by/4.0/.

\section{References}

1. Bullock RM (ed) (2010) Catalysis without precious metals. Wiley, Weinheim

2. Valyaev DA, Lavigne G, Lugan N (2016) Coord Chem Rev 308:191

3. Weber S, Kirchner K (2020) The role of metal-ligand cooperation in manganese(I)-catalyzed hydrogenation/dehydrogenation reactions. In: Topics in organometallic chemistry. Springer, Berlin

4. Mukherjee A, Nerush A, Leitus G, Shimon LJW, Ben-David Y, Espinosa-Jalapa NA, Milstein D (2016) J Am Chem Soc 138:4298

5. Mastalir M, Glatz M, Gorgas N, Stöger B, Pittenauer E, Allmaier G, Veiros LF, Kirchner K (2016) Chem Eur J 22:12316

6. Mastalir M, Glatz M, Pittenauer E, Allmaier G, Kirchner K (2016) J Am Chem Soc 138:15543

7. Deibl N, Kempe R (2017) Angew Chem Int Ed 56:1663

8. Huang M, Li Y, Liu J, Shu S, Liu Y, Ke Z (2019) Chem Comm 55:6213

9. Neumann J, Elangovan S, Spannenberg A, Junge K, Beller M (2017) Chem Eur J 23:5410

10. Bruneau-Voisine A, Wang D, Dorcet V, Roisnel T, Darcel C, Sortais JB (2017) J Catal 347:57

11. Elangovan S, Topf C, Fischer S, Jiao H, Spannenberg A, Baumann W, Ludwig R, Junge K, Beller M (2016) J Am Chem Soc 138:8809

12. Kallmeier F, Irrgang T, Dietel T, Kempe R (2016) Angew Chem Int Ed 55:11806

13. Weber S, Stöger B, Kirchner K (2016) Org Lett 20:7212

14. Bruneau-Voisine A, Wang D, Roisnel T, Darcel C, Sortais JB (2017) Catal Comm 92:1
15. Glatz M, Stöger B, Himmelbauer D, Veiros LF, Kirchner K (2018) ACS Catal 8:4009

16. Weber S, Stöger B, Veiros LF, Kirchner K (2019) ACS Catal 9:9715

17. Espinosa-Jalapa NA, Nerush A, Shimon LJW, Leitus G, Avram L, Ben-David Y, Milstein D (2017) Chem Eur J 23:5934

18. Weber S, Veiros LF, Kirchner K (2019) Adv Synth Catal 361:5412

19. Marciniec B (ed) (1992) Comprehensive handbook on hydrosilylation. Pergamon Press, Oxford

20. Marciniec B (ed) (2009) Hydrosilylation: a comprehensive review on recent advances. Springer, Berlin

21. Yates RL (1982) J Catal 78:111

22. Hanna PK, Gregg BT, Cutler AR (1991) Organometallics 10:31

23. Son SU, Paik SJ, Lee IS, Lee YA, Chung YK, Seok WK, Lee HN (1999) Organometallics 18:4114

24. Chidara VK, Du G (2013) Organometallics 32:5034

25. Pinto M, Friaes S, Franco F, Llortet-Fillol J, Royo B (2018) ChemCatChem 10:2734

26. Ma X, Zuo Z, Liu G, Huang Z (2017) ACS Omega 2:4688

27. Wenz J, Vasilenko V, Kochan A, Wadepohl H, Gade LH (2017) Eur J Inorg Chem 2017:5545

28. Mukhopadhyay TK, Flores M, Groy TL, Trovitch RJ (2013) J Am Chem Soc 136:882

29. Mukhopadhyay TK, Rock CL, Hong M, Ashley DC, Groy TL, Baik MH, Trovitch RJ (2017) J Am Chem Soc 139:4901

30. Igarashi M, Fuchikami T (2001) Tetrahydron Lett 42:1945

31. Arias-Ugarte R, Sharma HK, Morris ALC, Pannell KH (2011) J Am Chem Soc 134:848

32. Kelly CM, McDonald R, Sydora OL, Stradiotto M, Turculet L (2017) Angew Chem Int Ed 56:15901

33. Zhang J, Chevance S, Darcel C, Sortais JB (2013) Chem Commun 49:10010

34. Pratt SL, Faltynek RA (1983) J Organomet Chem 258:C5

35. Docherty JH, Peng J, Dominey AP, Thomas SP (2017) Nat Chem 9:595

36. Mukhopadhyay TK, Flores M, Groy TL, Trovitch RJ (2018) Chem Sci 9:7673

37. Yang X, Wang C (2018) Angew Chem Int Ed 57:923

38. Lavis JM, Maleczka RE Jr (2003) Polymethylhydrosiloxane encyclopedia of reagents for organic synthesis. Wiley

39. Perrin DD, Armarego WLF (1988) Purification of laboratory chemicals, 3rd edn. Pergamon, New York

40. Glatz M, Pecak J, Haager L, Stöger B, Kirchner K (2019) Monatsh Chem 150:111

41. Beritini F, Glatz M, Gorgas N, Stöger B, Peruzzini M, Veiros LF, Kirchner K, Gonsalvi L (2017) Chem Sci 8:5024

42. Bruneau-Voisine A, Wang D, Dorcet V, Roisnel T, Darcel C, Sortais JB (2017) Org Lett 19:3656

43. Fernandes JLN, Costa de Souza M, Brenelli ECS, Brenelli JA (2009) Synthesis 23:4058

44. Bhattacharya P, Krause J, Guan H (2011) Organometallics 30:4720

45. Kuriyama M, Shimazawa R, Shirai R (2008) J Org Chem 73:1597

46. Hatano M, Suzuki S, Ishihara K (2006) J Am Chem Soc 128:9998

47. Coombs TC, Lee MD, Wong H, Armstrong M, Cheng B, Chen W, Moretto AF, Liebeskind LS (2008) J Org Chem 73:882

48. Hemantha H, Sureshbabu VV (2011) Org Biomol Chem 9:2597

49. Weber S, Brünig J, Zeindlhofer V, Schröder C, Stöger B, Limbeck A, Kirchner K, Bica K (2018) ChemCatChem 10:4386

Publisher's Note Springer Nature remains neutral with regard to jurisdictional claims in published maps and institutional affiliations. 